\title{
Sosial kredit sistemlərində fərdi məlumatların idarə edilməsi problemləri
}

\author{
İradə Oləkbərova \\ AMEA İnformasiya Texnologiyaları İnstitutu, Bak1, Azərbaycan \\ airada.09@gmail.com
}

\begin{abstract}
Xülasə- İnformasiya texnologiyalarının inkişafı vətəndaşların fərdi məlumatlarının dövlət təşkilatları və özəl şirkətlər tərəfindən toplanması və emalı üçün yeni imkanlar yaratmışdır. Sosial media, izləmə cihazları, üz tanıma və "ağıllı şəhər" kimi texnologiyaların tətbiqi dövlətlərdə müşahidə cəmiyyətinin formalaşmasına səbəb olmuşdur. Məqalədə müşahidə cəmiyyətinin insanların gündəlik həyatına təsirləri, Çinin sosial kredit sisteminin fərdi məlumatların qorunması ilə əlaqədar beynəlxalq-hüquqi prinsiplərə nə dərəcədə uyğun olması araşdırılmışdır. Tədqiqatın məqsədi müşahidə cəmiyyətinin vətəndaşların sosial kreditinin qiymətləndirilməsində rolunu və yaratdığı problemləri müəyyənləşdirməkdir.
\end{abstract}

Açar sözlor- fordi molumatlar; sosial kredit sistemi; müşahido comiyyoti; votondaşın davranışı; üz tanıma sistemi; müşahido kamerast

\section{GİRIŞ}

İnformasiya və biliyin cəmiyyətdə rolu artdıqca dövlət orqanları və şirkətlər tərəfindən qeyri-maddi sistemin formalaşması, işçilərin yaradıcı potensialından maksimum istifadə, sosial tərəfdaşlığın yeni formalarının yaranması kimi sosial hadisələrə daha çox əhəmiyyət verilir. Dövlət təşkilatları və nəhəng şirkətlər tərəfindən müxtəlif informasiya sistemləri vasitəsilə fərdi məlumatların toplanması və emalı əsasən aşağıdakı məsələlərin həllinə yönəlmişdir:

ölkədə informasiya təhlükəsizliyinin təmini;

sosial-iqtisadi və sosial-siyasi məsələlərin səmərəli həlli;

vətəndaşların həyat şəraitinin yaxşılaşdırılması;

şirkətlərdə maliyyə risklərinin azaldılması və proqnozlaşdırma;

vətəndaşların cəmiyyətdə çəkisi, qanun qarşısında vəzifəsi, sosial normalara necə əməl etməsi və etimadı ilə əlaqədar vəziyyətin öyrənilməsi;

vətəndaş məmnuniyyətinin müəyyən olunması və $\mathrm{s}$.

$\mathrm{Bu}$ məsələlərin həllində tətbiq olunan yeni yanaşma kimi Çinin sosial kredit sistemini (Social Credit System, SCS) göstərmək olar [1]. Çin Xalq Respublikasının ayrı-ayrı bölgələrində sınaqdan keçirilən və 2020-ci ildə tətbiqi nəzərdə tutulan sistem korrupsiya və bürokratiyanın qarşısını almaqla ölkədə sosial bərabərsizliyi aradan qaldırmaq, yüksək iqtisadi inkişafa nail olmaq məqsədi ilə yaradılmışdır [2, 3]. SCS ölkə vətəndaşlarının və müxtəlif şirkətlərin fəaliyyətinə yüksək səviyyədə nəzarət etməklə ölkədə nümunəvi hüquqi dövlətin zəmanəti ola biləcək dünyada ilk milli qiymətləndirmə sistemi sayılır [4]. Lakin sosial kreditin qiymətləndirilməsində fərdi məlumatlardan istifadə ilə bağlı şəffaflığın olmaması, müşahidə cəmiyyətinin vətəndaşların gündəlik həyatlarına təsiri, fərdi məlumatların emalı nəticəsində vətəndaşlara qarşı cəza sisteminin tətbiqi bu sahədə ciddi problemlərin olduğunu göstərir.

\section{MÜŞAHİDӘ CӘMIYYӘTİ}

Müasir şəbəkə texnologiyaları insanların fərdi həyatı, davranışları, maraqlarının ayrılmaz hissəsinə çevrilməklə, müşahidə comiyyətinin (ing. Surveillance society) formalaşmasına səbəb olmuşdur [5]. Müşahidə cəmiyyəti dövlət təşkilatları, ayrı-ayrı şirkətlər və hətta cinayətkarlar tərəfindən vətəndaşları izləməyə, onların fəaliyyətini bütün gün ərzində nəzarətdə saxlamağa şərait yaradan cəmiyyətdir.

Oşyaların interneti, sosial şəbəkələr, izləmə cihazları, mobil əlaqələndirmə vasitələri, üz tanıma sistemləri və s. kimi müasir texnologiyalar müşahidə cəmiyyətində əsas izləmə vasitələridir. $\mathrm{Bu}$ vasitələrdən toplanan fərdi məlumatlar vətəndaşın səhhəti, maraqları, psixoloji durumu, evdə və ictimai yerlərdə davranışı, intellektini qiymətləndirməyə və proqnozlaşdırmağa imkan yaradır [6].

İzləmə cihazları ilə toplanan fərdi məlumatlar digər məlumatlar kimi müxtəlif bazalarda - bank və sığorta şirkətlərinin, tədris və tibb müəssisələrinin, supermarket və dövlət idarələrinin informasiya sistemlərində, müxtəlif arxivlərdə saxlanılır. Rəqəmsallaşdırılmış bu məlumatlar insanların davranışlarını və sosial münasibətləri, ölkədəki demoqrafik prosesləri, bazar iqtisadiyyatını idarə etmək üsullarını dəyişdirir. Ayrı-ayrı şirkətlər və təşkilatlar tərəfindən yüksək gəlir əldə etmək, maliyyə risklərini azaltmaq, informasiya təhlükəsizliyini təmin etmək üçün əməkdaşların, müştərilərin, iş ortaqlarının və $\mathrm{s}$. haqqında fərdi 
məlumatların toplanması ənənəvi hal almışdır. Artıq biznesdə, müxtəlif idarəetmə formalarında, insanlar arasında informasiya mübadiləsində vətəndaşı müəyyən edən ənənəvi əlamətlər: adı, yaşadığı yer, doğulduğu tarix, təhsili və biliyi kifayət deyil.

Fərdi məlumatların ilkin mənbəyi, müşahidə cəmiyyətinin təməli kimi İnternet qlobal şəbəkəsi xüsusi yer tutur. Müşahidə cəmiyyətinin inkişafi ilə əlaqədar fərdi məlumatlar siyahısına yeni verilənlər daxil edilir: vətəndaşın veb portallardak1 istifadəçi hesabı, e-poçt ünvanı, mobil telefon nömrəsi, kredit tarixi, sosial kapitalı və s. Burada əsas problemlərdən biri vətəndaşın fərdi məlumatları əsasında identifikasiya aparan tərəfin nə qədər etibarlı olmasıdır.

İzləmə cihazlarından istifadə etməklə fərdi məlumatların ələ keçirilməsi onlardan icazəsiz istifadə problemlərini də aktuallaşdırmışdır. Bu gün sosial media imkanlarından istifadə etməklə hər hansı vətəndaş haqqında fərdi məlumatların icazəsiz və qərəzli şəkildə ictimaiyyətə ötürülməsi ilə istənilən vətəndaşın nüfuzuna və sosial-iqtisadi vəziyyətinə zərbə vurmaq təhlükəsi mövcuddur.

Dövlət portallarında, virtual ensiklopediyalarda, virtual ticarət şəbəkələrində də vətəndaşlar haqqında fərdi məlumatlar toplanmaqdadır. Bu məlumatlar iki formada olur: açıq şəkildə verilən fərdi məlumatlar və digər məlumatların emalı nəticəsində əldə edilən gizli fərdi məlumatlar. Vətəndaşların informasiya daxil edərkən səhlənkarlığı, heç bir əsas olmadan başqalarına etimad1, onlayn və avtonom identifikasiya məlumatlarının düzgün idarə olunmaması fərdi məlumatların cinayətkarların və ya dələduz şirkətlərin əlinə keçməsinə səbəb olur.

\section{SOSİAL KREDİT SISTEMI}

Çin Xalq Respublikasında "Xəbərdarlıq və cəza" sistemi adlandırılan SCS bir sıra qərb dövlətləri tərəfindən tənqid edilməkdədir. Qərb mətbuatında belə bir fikir formalaşı ki, SCS bütün Çin vətəndaşlarının fərdi məlumatlar əsasında qiymətləndirilməsini aparmaqla əhaliyə nəzarət edir və vətəndaşları davranışına görə cəzalandırmaq funksiyası daşıyır. Onlar sistemin vətəndaşın fəaliyyətinə nəzarət etməsini demokratiyanın pozulması, fərdi məlumatlarından vvətəndaşa qarşı istifadə olunmasının repressiyaya gətirib çıxaracağını iddia edirlər $[7,8]$. Lakin Çin hökuməti bu iddiaları əsassız sayır və SCS-in sosial-iqtisadi sahələrdə risklərin idarə olunmasında, cəmiyyətin təhlükəsizliyi və iqtisadi inkişafinda mühüm vasitə olduğunu iddia edir.

Fərdi məlumatların mühafizə olunmasının əsas prinsipləri BMT-nin "Ümumdünya İnsan Hüquqları Bəyannaməsi”ndə (ing. Universal Declaration of Human Rights) öz əksini tapmışdır [9]. BMT Baş Assambleyasının 16 May 2011-ci il tarixli məruzəsində bildirilir ki, "İnternet" informasiya və telekommunikasiya şəbəkəsinə müraciət imkanının yaradılması insan hüquqlarının baza hissəsinə aiddir və "İnternet" informasiya və telekommunikasiya şəbəkəsinə çıxışın məhdudlaşdırılması və vətəndaşın fərdi məlumatlarının həmin vətəndaşın icazəsi olmadan yayılması vətəndaş hüquqlarının pozulması kimi tanınır. Lakin bu gün SCS-in işinə qoyulan tələblər bunun əksini göstərir. Sistemin əsas funksiyası olan sosial kreditin qiymətləndirilməsi məsələsi ölkə ərazisində fəaliyyət göstərən bütün təşkilatlar arasında hərtərəfli əlaqələndirməni təmin edən və vətəndaşlar haqqında bütün fərdi məlumatları toplamaq imkanına malik nəhəng verilənlər bazası tələb edir.

\section{IV. ÇININ MÜŞAHIDӘ CəMIYYӘTi}

Çin Xalq Respublikasında ölkə vətəndaşlarını izləmək üçün video və şəkil çəkən qurğuların sayı və əhatə dairəsi heyrətləndiricidir. 2018-ci ilin iyul ayında New York Times Çində təxminən 200 milyon nəzarət kamerasının olduğunu bildirmişdir və bu nəzarət kameralarının sayı ABŞ-dan 4 dəfə çoxdur [10].

Vətəndaşların gündəlik fəaliyyətlərinin izlənməsində son illərdə robot quşlardan geniş istifadə olunmaqdadır. 30-dan çox hərbi və dövlət qurumları Çinin müxtəlif əyalətində insanları izləmək üçün dronlardan və buna oxşar uçan müşahidə qurğularından istifadə etməkdədir. Real göyərçinlərin hərəkətlərinin 90 faizini təqlid edən robot quşlar müşahidə kameraları, GPS, uçuş idarəetmə sistemi və peyk rabitəsi vasitəsilə məlumat ötürülməsi üçün anten ilə təchiz edilmişlər [11].

Müşahidə cəmiyyətinin inkişaf etdirilməsi üçün Çin hökumət dairələrində müxtəlif yanaşmalardan istifadə olunur. Məsələn "Hukou (household registration)" [12] və "Dang'an (personal archives)" [13] modelləri vətəndaşların fərdi məlumatları əsasında dövlət nəzarətini gücləndirmək üçün tətbiq edilmişdir. "Hukou" əsasən miqrasiyaya nəzarət edir və əhalinin kəndlərdən şəhərlərə axınının qarşısını almaq üçün nəzərdə tutulmuşdur. "Dang'an" modeli isə fərdi məlumatların (identifikasiya nömrəsi, məşğulluğu, təhsili və s.) arxivləşdirilməsini yerinə yetirir və qapalıdır. Son illər informasiya texnologiyalarının inkişafı ilə Çində "İnternet senzura" və "böyük verilənlərin analitikası" kimi daha mürəkkəb modellərin tətbiqinə keçilmişdir [8, 14].

Dövlət təşkilatları tərəfindən tətbiq olunan milyonlarla nəzarət qurğuları və müxtəlif analitik sistemlər belə deməyə əsas verir ki, hökümət vətəndaşların fərdi məlumatlarına nəzarət mexanizmlərini tez bir zamanda modernləşdirməkdə maraqlıdır. Çinin müşahidə cəmiyyəti SCS-in tətbiqi ilə çox sürətlə inkişaf edir. 2010-cu ildən başlayaraq Çin hökuməti “ağıllı şəhər”lərin pilot layihələrini genişləndirməkdə davam edir. Artıq Çinin 500 şəhəri bu layihəyə qoşulmuşdur. Çində "Sky Net" layihəsinə əsasən iri şəhərlərdə 20 milyondan artıq küçə müşahidə kameraları vətəndaşların üzə görə tanınmasını həyata keçirir. Kameralardan əldə olunan məlumatlar SCS-ə ötürülərək emal olunur [14].

\section{SOSİAL KREDİT SISTEMLORINNDӘ FORDİ MəLUMATLARIN İDARӘ EDİLMOSİ PROBLEMLӘRİ}

Üz tanıma sistemi, əşyaların İnterneti və digər izləyici qurğularla əlaqəli işi SCS-in daha geniş bir alqoritmik idarəetmə modelinə malik olması və ayrı-ayrı şəxslərin statistik və analitik təhlilində fərdi məlumatlardan geniş 
istifadə olunduğunu göstərir. SCS-də fərdi məlumatların hans1 mənbələrdən toplanması və necə emal olunması haqqinda məlumat verilmir. $\mathrm{Bu}$ baxımdan fərdi məlumatların toplanmasında hüquqi normalara nə dərəcədə əməl olunması məlum deyil.

SCS tərəfindən fərdi məlumatların toplanması və emalında qaranlıq məqamların olması cəmiyyətdə qeyri-müəyyənliyə səbəb olur, elektron xidmətlərdən istifadə etimadını sarsıdır və nəticədə informasiya cəmiyyətinin inkişafına təhdid yaradır [15].

Hər bir informasiya sistemində olduğu kimi, SCS-də tətbiq olunan alqoritmlərdə xətaların olması ehtimalı vardır. Sistemin işindəki ümumi xətalar kimi aşağıdakıları göstərmək olar:

SCS-də emal olunan verilənlərin mənbələrində və tətbiq olunan alqoritmlərdə qeyri-şəffaflığın olması;

sistemdə emal olunan informasiyanın həddən artıq böyük və mürəkkəb olması nəticəsində baş verən xətalar;

sistem operatorunun diqqətsizliyindən yaranan xətalar;

sistemə daxil edilən informasiyanın qeyri-dəqiqliyi və alqoritmdəki texniki xətalar.

Sistemin müəyyən etdiyi sosial kredit vətəndaşı qane etmirsə və ya vətəndaş bu qiymətləndirmənin necə əldə olunduğu haqqında təsəvvürü yoxdursa, bu halda sual yaranır: SCS tərəfindən verilən sosial kreditlə razı olmayan vətəndaş hara müraciət etməlidir? Çünki sosial kredit yalnız vətəndaşın özünə deyil, onun ailəsinə və uşaqlarının sosial-iqtisadi həyatına da ciddi təsir göstərir. Məsələn, sosial krediti aşağ olan vətəndaş dövlət tərəfindən etimadsız sayılır. Nəticədə, həmin vətəndaş dövlət işində işləyə bilməz, uşağını nüfuzlu məktəb və universitetlərdə oxuda bilməz və s. Buradan belə nəticəyə gəlmək olar ki, SCS vasitəsilə hökumət vətəndaşların davranışlarını istədiyi istiqamətə yönəltmək və formalaşdırmaq imkanına malik olur. Bundan əlavə, alqoritmlər ictimaiyyətə açıqlanmadığından müəyyən etnik qrupların, dini və milli azlıqların bu sistemdən əziyyət çəkmə riski vardır.

Son illər cəmiyyətdə Çin şirkətləri tərəfindən fərdi məlumatlardan sui-istifadə hallarına qarşı tələblər güclənmişdir [16]. Məsələn, istehlakçı hüquqlarının müdafiəsi təşkilatı istifadəçi razılığı olmadan istifadəçinin olduğu yer, mesajları və sosial münasibətləri kimi şəxsi məlumatları icazəsiz topladığına görə dünyanın ən nəhəng axtarış sistemi olan və Çin hökuməti tərəfindən dəstəklənən Baidu-nu məhkəməyə vermiş və nəticədə, Alipay internet xidmətinin idarə heyəti “Ant Financial's” təşkilatından üzr istəmişdir.

SCS-in əhəmiyyətli olduğunu bildirən Çinin dövlət orqanları vətəndaşların fərdi məlumatlarının qorunmasının vacibliyi məsələsinə toxunmurlar. Çində vətəndaşların fərdi məlumatlarının təhlükəsizliyi məsələsinin açıq qalması vətəndaşların kütləvi izlənməsi və bütün fərdi məlumatların toplanaraq emal edilməsi məsələsinə hüquqi cəhətdən azadlıq verilmişdir. Belə bir şəraitdə SCS-in tətbiqi fərdi məlumatların təhlükəsizliyi məsələsində vətəndaşlara ciddi problemlər yaratmışdır.

Çinin hakim dairələri bildirirlər ki, fərdi məlumatları emal etməklə vətəndaşların sosial kreditini müəyyən edən SCS məsuliyyətli vətəndaşların sayının xeyli artmasına imkan yaradacaqdır. Belə ki, öz sosial kredit balını artırmağa çalışan vətəndaş davranışlarına daha ciddi yanaşacaq və əmək fəaliyyətində, virtual məkanda və müxtəlif növ ödəmələrdə dəqiq olmağa, səhvlərə yol verməməyə çalışacaqdır. SCS ilə əlaqədar sənədlərdə göstərilir ki, sistemin səmərəli işi üçün hökumət vətəndaşların və Çində fəaliyyət göstərən bütün təşkilatların qiymətləndirilməsi üçün fərdi məlumatlardan, maliyyə, hüquqi və digər verilənlərdən sərbəst istifadə və sosial krediti kifayət qədər olmayan şəxsləri və təşkilatları cəzalandırmaq hüququna malikdir [17]. SCS-in işindəki "xəbərdarlıq və cəza" prinsipinin dövlət qanunları ilə uyğunluğu problemlər yaradır və onlar aşağıdakılardır:

Sosial kreditin müəyyən olunmasının qanunvericilikdə şərtləri göstərilmir.

Hüquqi sənədlərdə milli qiymətləndirmə agentliklərinin olması haqqında dəqiq məlumat yoxdur.

\section{Qiymətləndirmə agentliklərinin fəaliyyətində tənzimləyici şərtlər mövcud deyil.}

Təhlükəsiz, mərkəzsizləşdirilmiş verilənlər bazası yaratmaq üçün verilənlərin izləyici qurğulardan, üz tanıma sistemləri və sosial media vasitələrindən toplanması və düzgün strukturlaşdırılması nəzərdə tutulsa da fundamental idarəetmə problemləri hələ də qalmaqdadır.

\section{NəTIC๐}

Araşdırmalardan məlum oldu ki, Çinin müxtəlif bölgələrində sinaqdan keçirilən SCS-də tətbiq olunan cəza prinsipinin vətəndaşın hüquqlarını nə dərəcədə pozduğu və ya müdafiə etdiyi hələ də tam tədqiq olunmayı. Sosial kreditin qitmətləndirilməsi əsasında vətəndaşın etimadının pozulmasını qanun pozuntusu kimi göstərmək üçün, bu, əvvəlcə hüquqi sənədlərdə öz əksini tapmalıdır. $\mathrm{Bu}$ səbəbdən, SCS-in dövlət idarəçiliyinə inteqrasiyasını yalnız dövlətdə hüquq anlayışının hərtərəfli yenidən nəzərdən keçirilməsindən sonra mümkün olacaqdır. SCS tətbiqi ilə ölkə vətəndaşlarının cəzalandırılması üsullarında yaranan yeni yanaşmalar qanun çərçivəsində həyata keçirilməlidir. Belə ki, sistemin müəyyən etdiyi cəza prinsipi dövlətin hüquqi sənədlərində öz əksini tapmayıbsa, sosial kreditə görə cəzalandırma qanunsuz hesab olunmalıdır.

Hər bir vətəndaşın və təşkilatın fərdi məlumatlarını nəzarətdə saxlamaq imkanına malik olması onun cəmiyyətdə etimad əldə etmək və nüfuz sahibinə çevrilməsinin həlledici faktorudur. Fərdi məlumatların təhlükəsizliyi, məxfilik, şəffaflıq və cavabdehlik İnternet istifadəçilərinin fəaliyyətindən ön planda olmalı, şəbəkə texnologiyalarında nəzərə alınmalıdır. Fərdi məlumatların məxfiliyinin müxtəlif aspektləri mövcuddur. Bunlar milli 
dəyərlər, mədəniyyət, sosial normalar, iqtisadiyyat, vətəndaş hüquqları ilə bağlıdır.

Araşdırmadan məlum oldu ki, informasiya texnologiyalarının inkişafı müşahidə cəmiyyətinin genişlənməsinə səbəb olmuşdur ki, bu da fərdi məlumatların təhlükəsizliyi problemini daha da aktuallaşdırmışdır. Müşahidə kameraları, üz tanıma sistemləri, süni intellektlə təchiz olunmuş dronlar, "əşyaların İnterneti" kimi müasir texnologiyalar vətəndaşların gündəlik həyatlarına müdaxilə edərək, davranışlarını qeydə alır. Vətəndaşların şəxsi həyatına müdaxilə, onların sosial-iqtisadi durumlarının informasiya sistemlərindən asılı vəziyyətə gətirilməsi demokratik dəyərlərə, "fərdi məlumatlardan vətəndaşın icazəsi olmadan istifadə edilə bilməz" prinsiplərinə ziddir. Lakin digər tərəfdən dövlətlərin informasiya təhlükəsizliyi, iqtisadi inkişafı, vətəndaşların rifahı, cinayətlərin qarşısının alınması və bir sıra həlli vacib məsələlərdə müşahidə cəmiyyətinin əhəmiyyəti böyükdür.

\section{İSTINADLAR}

[1] M. Blomberg, "The social credit system and China's rule of law," Mapping China Journal, 2018, no. 2, pp. 77-162.

[2] Chinese Social Credit System (I): what it is - and what it isn't, https://polikracia.com/the-chinese-social-credit-system/

[3] F.A.F. Ferreira, J.P. Esperanca, M.A.S. Xavier, et. al., "A sociotechnical approach to the evaluation of social credit applications," Operational Research Society, 2019, vol. 70, Issue 10, pp. 18011816.

[4] S. Engelmann, M. Chen, F. Fischer, et. al., "Clear sanctions, vague rewards: How china's social credit system currently defines "good" and "bad" behavior," Proceedings of the 2019 Conference On Fairness, Accountability, and Transparency, Atlanta, 2019, pp. 6978.

[5] K. Rannenberg, D. Royer, A. Deuker, "The future of identity in the information society: challenges and opportunities," Identity in the Information Society, 2010, vol. 3, issue 3, pp. 599-604.

[6] S. Matos, "Privacy and data protection in the surveillance society: The case of the Prum system," Forensic and Legal Medicine, 2019, vol. 66 , pp. $155-161$.

[7] B. Song, "Opinion the west may be wrong about China's social credit system," The World Post, 2018, https://www.washingtonpost.com/news/theworldpost/wp/2018/11/ 29/social-credit

[8] F. Liang, V. Das, N. Kostyuk, M.M. Hussain "Constructing a data driven society: China's social credit system as a state surveillance infrastructure," Policy and Internet, 10(4), pp. 415-453, 2018.

[9] Universal Declaration of Human Rights, https://www.un.org/en/universal-declaration-humanrights/index.html.

[10] P. Mozur, "Inside China's dystopian dreams: AI, shame and lots of cameras," The New York Times, 2018, https://www.nytimes.com/2018/07/08/ business/china-surveillancetechnology.html?module $=$ inline

[11] Z. Jiaquan, "Drones, facial recognition and a social credit system: 10 ways China watches its citizens," South China Morning Post, 2018, https://www.scmp.com/news/china/society/article/2157883/ drones-facial-recognition-and-social-credit-system-10-ways-china

[12] K.W. Chan, "The Household Registration System and Migrant Labor in China: Notes on a Debate," Population and Development Review, 2010, vol. 36, no. 2, pp. 357-364.

[13] W.W. Moss, "Dang'an: Contemporary Chinese Archives," The China Quarterly, 1996, no. 145, pp. 112-129.
[14] Y. Chen, A.S.Y. Cheung, "The Transparent Self Under Big Data Profiling: Privacy and Chinese Legislation on the Social Credit System," Comparative Law, 2017, vol. 12, no. 2, pp. 356-378.

[15] D.V. Rooy, J. Bus, "Trust and privacy in the future internet research perspective," Identity in the Information Society, 2010, vol. 3, issue 2, pp 397-404.

[16] M. Chorzempa, P. Triolo, S. Sacks, "China's Social Credit System: A Mark of Progress or a Threat to Privacy?" Peterson Institute for International Economics, 2018, 39 p.

[17] S.Y. Lei, "Beyond the Rule of Law: Rule-based Regulation under the Social Trustworthiness System," Social Science Edition (Central South University), 2014, no.4, pp. 65-72.

\section{PROMLEMS OF PERSONAL DATA MANAGEMENT IN SOCIAL CREDIT SYSTEMS}

\author{
Irada Alakbarova
}

Institute of Information Technologies of ANAS, Baku, Azerbaijan airada.09@gmail.com

Abstract - The development of information technology has created new opportunities for the collection and processing of personal data of citizens by state bodies and private companies. The use of social networks, tracking devices, face recognition and technologies such as the "smart city" has led to the formation of an surveillance society in countries. The article discusses the impact of surveillance society on people's daily lives, as well as the degree to which China's social credit system is in compliance with international legal principles for the protection of personal data. The aim of the study is to identify the role and problems of the surveillance society in assessing social loans of citizens.

Key words - personal data; social credit system; observation society; citizen behavior; face recognition system; surveillance camera 